no. ERDC/CHL SR-00-1 c. 3

\section{LIBPARY USE ONLY}

U $=C E=C$ Property of the

United States Government
ITI I

I I I I

US Army Corps of Engineers $\odot$

Engineer Research and Development Center

\title{
Site Visit and Evaluation of New Cremona Lock Filling and Emptying System
}

Phil G. Combs

March 2000

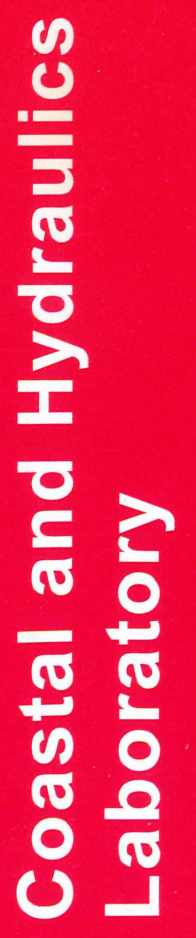




\title{
Site Visit and Evaluation of New Cremona \\ Lock Filling and Emptying System
}

by Phil G. Combs

Coastal and Hydraulics Laboratory

U.S. Army Engineer Research and Development Center

3909 Halls Ferry Road

Vicksburg, MS 39180-6199

Final report

Approved for public release; distribution is unlimited

\author{
Prepared for Dr. Luigi Natale \\ HYDRAW srl \\ S. Agata, 10 \\ 27100 Pavia, Italy
}




\section{U.S. Army Engineer Research and Development Center Cataloging-in-Publication Data}

\section{Combs, Phil G.}

Site visit and evaluation of New Cremona Lock filling and emptying system / by Phil G. Combs ; prepared for Dr. Luigi Natale, HYDRAW srl.

41 p. : ill. ; $28 \mathrm{~cm}$. - (ERDC/CHL ; SR-00-1)

Includes bibliographic references.

1. Locks (Hydraulic engineering) - Italy - Po River - Design and construction. 2. Po River (Italy) 3. Cremona Lock (Italy) 4. Cremona (Italy) I. United States. Army. Corps of Engineers. II. U.S. Army Engineer Research and Development Center. III. Coastal and Hydraulics Laboratory (U.S.) IV. Title. V. Series: ERDC/CHL SR ; 00-1.

TA7 E8 no.ERDC/CHL SR-00-1 


\section{Contents}

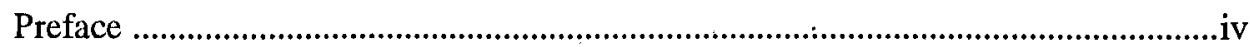

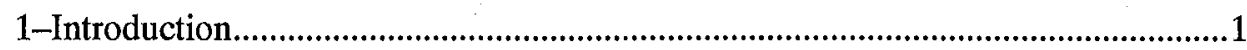

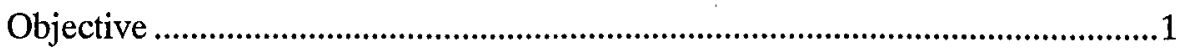

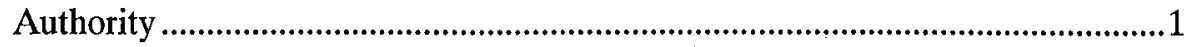

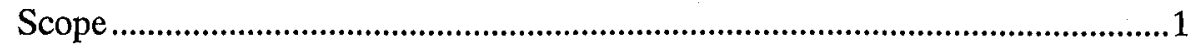

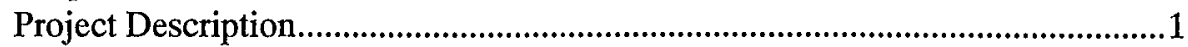

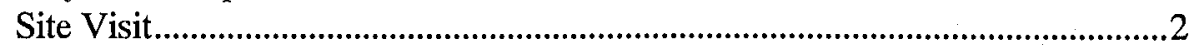

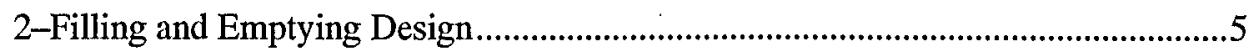

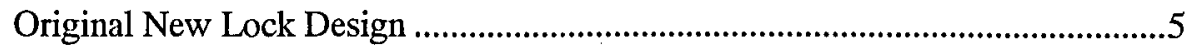

Revised New Lock Design..................................................................................5

Appendix A: Cooperative Research and Development .........................................A1

Appendix B: Trip Report..............................................................................

SF 298 


\section{Preface}

The work described herein was performed in the Coastal and Hydraulics Laboratory (CHL), of the U.S. Army Engineer Waterways Experiment Station (WES) as part of a Cooperative Research and Development Agreement (CRDA), WES Agreement No. WES-97-CHL-07, with Dr. Luigi Natale, Pavia, Italy. WES has now become part of the U.S. Army Engineer Research and Development Center (ERDC). The CRDA entailed collaborative research involving innovative techniques for design of navigation locks to be incorporated into a replacement lock at Cremona, Italy. This report presents findings and recommendations of the collaborative efforts.

The work was conducted from July 1997 to October 1998 under the direction of the following personnel: Dr. James R. Houston, Director, CHL; Mr. Charles Calhoun, Assistant Director, CHL; and Dr. Phil G. Combs, Chief, Rivers and Structures Division, CHL.

Dr. Combs prepared this report with significant assistance from Dr. John Hite, Locks and Conduits Group, Rivers and Structures Division.

At the time of publication of this report, Dr. Lewis E. Link was Acting Director of ERDC and COL Robin R. Cababa, EN, was Commander.

The contents of this report are not to be used for advertising, publication, or promotional purposes. Citation of trade names does not constitute an official endorsement or approval of the use of such commercial products. 


\section{Introduction}

\section{Objective}

The U.S. Army Engineer Waterways Experiment Station(WES) has been conducting research and development work into innovative techniques for design and construction of navigation locks since the early 1990's. Filling and emptying techniques for navigation locks have been used differently in Europe than in the United States. The objective of this effort was to allow WES engineers and Italian engineers to collaborate on research recommendations for the Cremona Replacement Lock as a means of exchanging technical knowledge in a collaborative manner.

\section{Authority}

This collaborative research and development effort was accomplished through the use of a Cooperative Research and Development Agreement(CRDA) between Dr. Luigi Natale and the WES. The Federal Technology Transfer Act of 1986 provided the authority for the Directors of Federal laboratories to enter into CRDAs with Federal or non-Federal entities. The CRDA utilized for this effort, WES-97-CHL-07, dated 30 September 1997, is attached as Appendix A.

\section{Scope}

The scope of this effort entailed a trip to the Cremona, Italy area to view the site of the proposed replacement lock and other similar structures, evaluation of the preliminary lock hydraulic design and utilization of recent research to make recommendations for improvement of the lock hydraulic performance.

\section{Project Description}

The existing project at Cremona, Itlay, consists of two inline navigation locks connecting the Po River to the port of Cremona and the inland canal. A vicinity map is shown in Figure 1. The lower lock is 12 meters wide and 133 meters long, while the upper lock is 12 meters wide and 226 meters long. The 


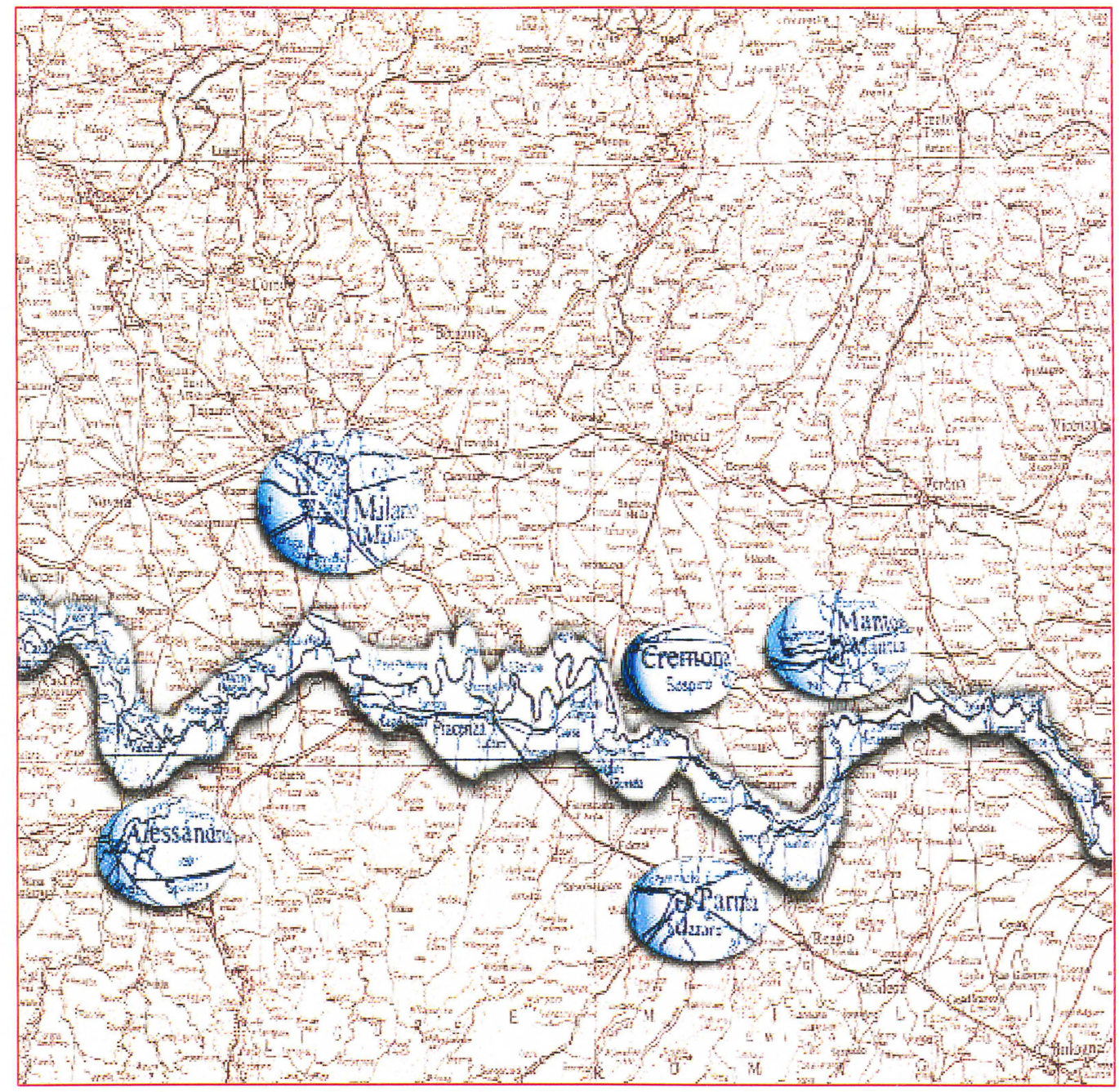

Figure 1. Location Map of Cremona, Itlay

downstream lock was constructed recently adjacent to the first lock, to accommodate for river degradation that has occurred on the Po River. The new lock was a steel structure floated into place and ballasted with concrete. The lock gates are vertical lift with the filling and emptying of the lock occurring under the lift gates. There is a supplemental set of gates at the 87 meter point to accommodate small navigation tows. The downstream gates on the "new" lock are miter gates. The maximum head designed for the locks is about 9.5 meters, which was experienced during the site visit. A replacement lock for these Cremona Locks is planned to fully accommodate the total expected degradation on the Po River, 6.5 meters.

\section{Site Visit}

A visit to the area of the Cremona Lock was conducted 25-29 October 1997, and the trip report is provided in Appendix B. The site visit provided the 
opportunity to visit the existing Cremona Locks, as well as other locks in the vicinity. In general, the Italian locks had vertical lift gates and provided filling and emptying under the gates. The Cremona Locks lockmaster conducted a filling and emptying cycle in each of the locks to demonstrate the method of filling and emptying. With heads approaching 5.5 meters, that was observed during the site visit, the filling was rapid and allowed significant turbulence in the chamber (Figures 2-4). There were no boats in the chamber during the filling and emptying operations. The Italians provide a barrier to protect the lock gates from boats that are moved during filling and emptying cycles.

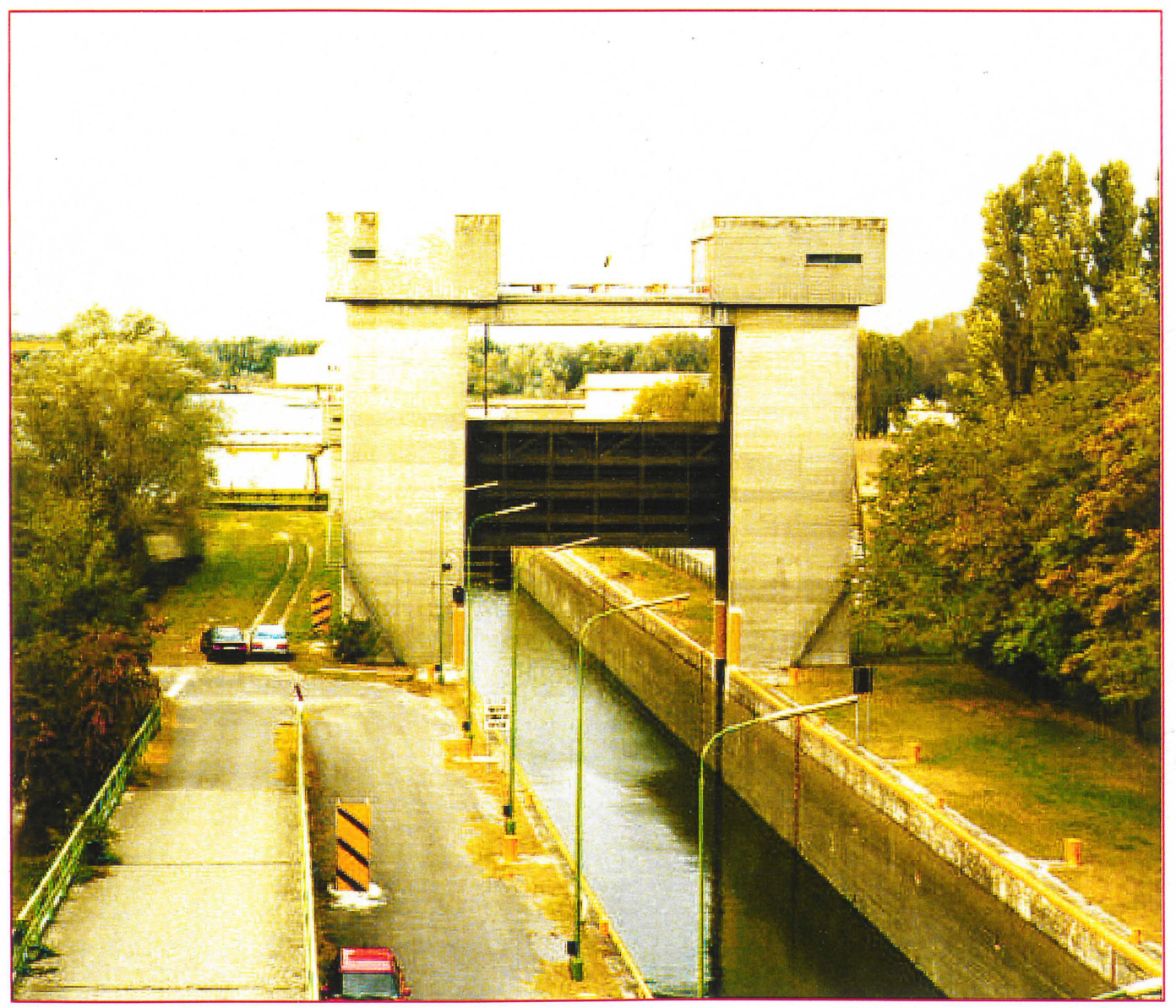

Figure 2. Existing upper Cremona Lock 


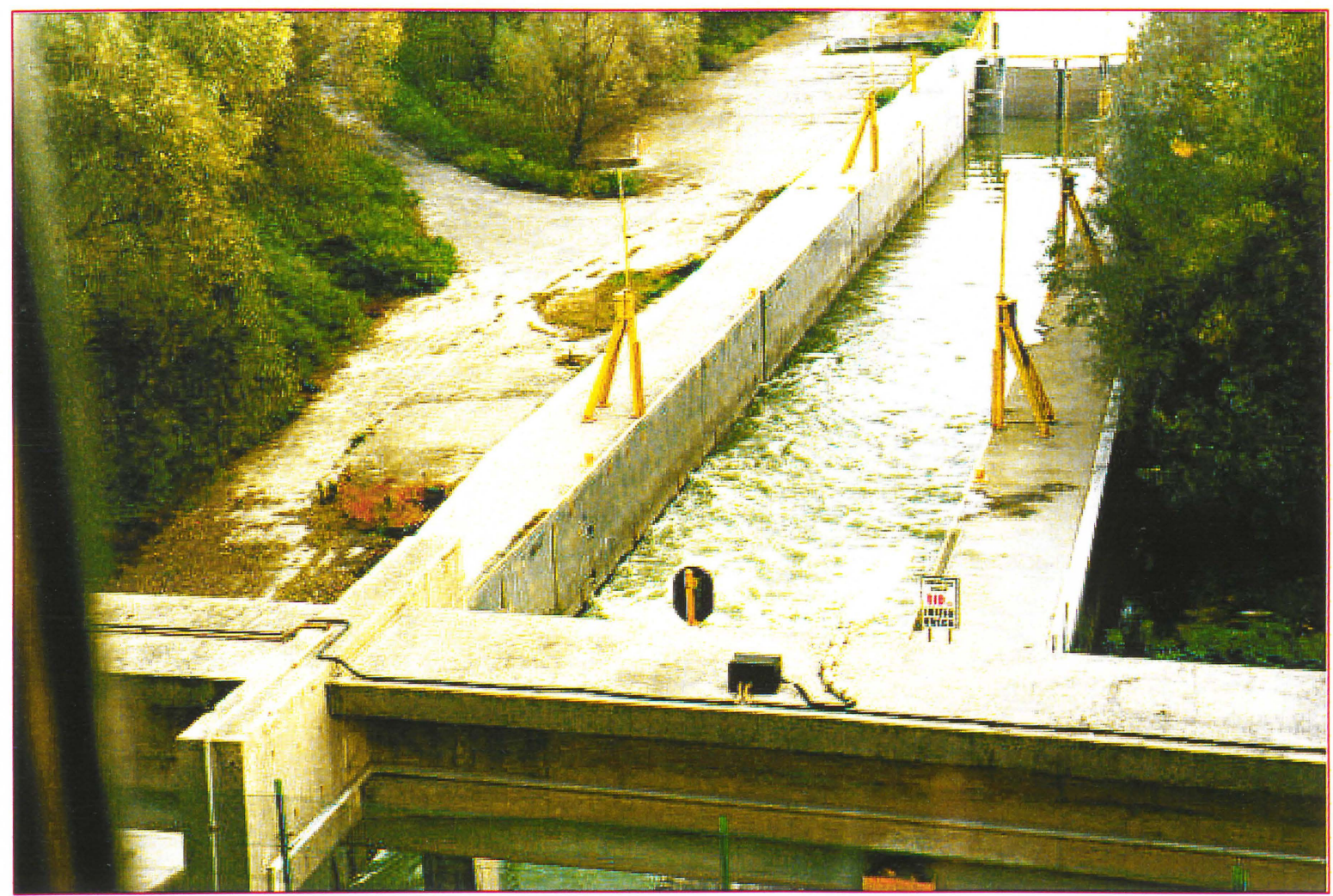

Figure 3. Existing lower Cremona Lock

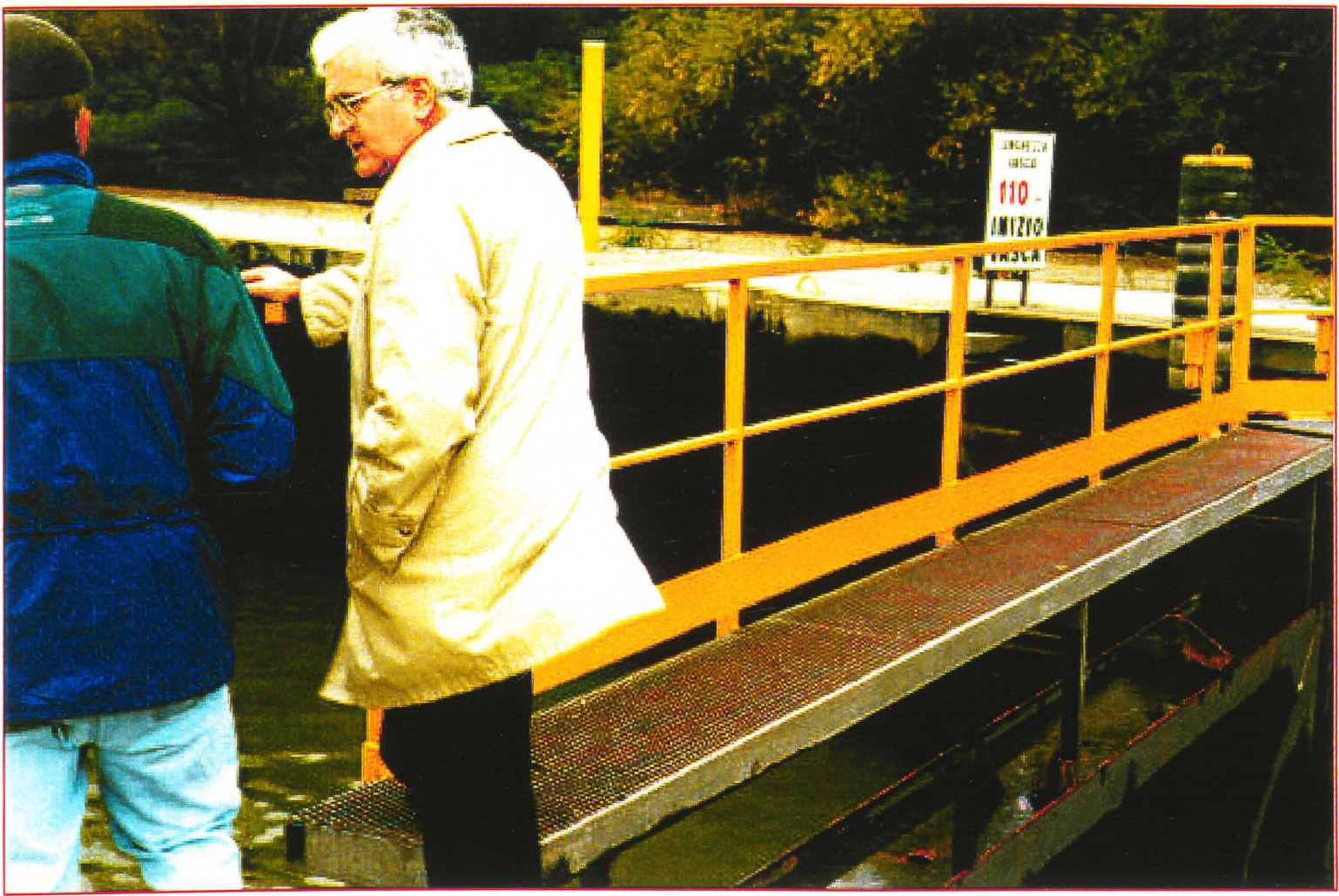

Figure 4. Existing lower Cremona Lock 


\section{Filling and Emptying Design}

The present upper lock has vertical lift end gates that provide filling and emptying under the end gates. The downstream gates on the lower lock are miter gates with the emptying occurring in wrap around culverts. Figure 5 is a plan and profile of the existing lock. The WES has found that the filling and emptying of navigation locks is a vital part of the overall design and operation. Excess lock filling and emptying turbulence can result in conditions that will cause stresses on barge tie ropes to significantly exceed the safe limit of 5 tons. Additionally, intakes to filling and emptying culverts and/or under slide gates must be evaluated to assure that vortices will not be damaging.

\section{Original New Lock Design}

The design of the new Cremona Lock included miter gates and filling and emptying at the ends of the lock. There are supplemental gates and wrap around culverts at the 80 meter location to accommodate small navigation tows and pleasure craft. The emptying at the downstream end of the lock was through wrap around culverts also. The filling of the lock at the upstream end was to be through a culvert, extending from within 1.5 meters from the upper pool to the lock floor. Upon review of the original design WES noted several problems and provided some suggested revisions for the lock intakes. Specifically, the culvert intakes were lowered to minimize the possibility of air entrainment, these are shown as Figures 6, 7 and 8.

\section{Revised New Lock Design}

The design of the Cremona lock was revised to include a distributed manifold filling and emptying system. The revised lock design, shown in Figures 9 and 10 , includes miter gates and a longitudinal manifold system for filling and emptying the lock. The longitudinal manifold filling system has performed well for medium to higher lift locks in the US. The design proposed for Cremona is different than any currently used by the Corps in the US. To work properly, each manifold must synchronously release the same flow rate. Unequal discharges will result in water-surface slopes within the chamber which will tend to move 
the moored vessel and barges. Excessive water-surface slopes will cause hawsers stresses sufficient to break tie ropes and risk damage to the lock gates. The design proposed for Cremona Lock should be verified using a physical model to determine chamber performance and operating characteristics. The Corps criteria for acceptable chamber performance is based on hawser forces that a moored vessel and barges will experience with the desired lock operation. Experience from numerous laboratory lock model investigations and a few prototype studies has shown that if the maximum longitudinal hawser force does not exceed 5 tons during a design filling operation, then the chamber performance is considered acceptable. Excessive water-surface turbulence should also be avoided to prevent danger to small craft. This criteria essentially requires that the watersurface slopes within the chamber remain minimal. Since the proposed Cremona Lock contains two culvert crossovers, it will be more difficult to maintain minimal water-surface slopes compared to one crossover in the middle of the chamber. Also because the flow is split only in the horizontal direction, at each of these crossovers, splitter piers in the wall culverts at the crossovers will probably have to be used to properly distribute the flow. The resulting flow division is quite sensitive to the size, shape, and position of the splitter piers. Bottom longitudinal manifold culverts perform best when the sum of the filling and emptying port area to the sum of the culvert area is unity.

\section{Discharge system}

The type discharge outlet proposed for the Cremona Lock has performed adequately at Corps Projects that use this type design. Discharging immediately downstream of the lower miter gates is convenient and generally less expensive than outlets which discharge outside the lock walls. Discharging below the lower miter gate will cause a surge in the lower approach and vessels moored in this area will experience high hawsers if the surge is large. Increased emtying times will reduce the surge heights, however this type operation is not recommended if cavitation conditions are possible. Recent Corps model investigations of the new Kentucky Lock have provided hawser force information for tows moored at diffferent locations along the downstream guide wall.

\section{Summary}

The design proposed for the Cremona Lock appears feasible, however the final design should be developed using a laboratory model. A 1:25-scale model is preferred to avoid excessive costs and scale effects. Scale effects will be present at this scale but they will not significantly alter the Froude-scale results. Prototype filling and emptying times will be slightly faster than those determined using a 1:25-scale Froude model. Model investigations have shown that significant improvements in lock filling and emptying performance can be achieved with relatively minor modifications to the system. Intake vortex formation can also be evaluated using a physical model if the approach flow and geometry are reproduced in detail. Vortex formation is highly dependent on the approach flow and the geometry surrounding the intake. Any appurtenance that affects the approach flow in the vicinity of the intake should be reproduced. A typical lock 
model investigation includes measuring both longitudinal and transverse hawser forces in the chamber as well as observing surface and subsurface flow patterns. The chamber modifications are evaluated based on these measurements and observations. Models also provide pressure data throughout the system which can be extremely important in locations immediately downstream from valves and on the inside of the crossover bends. 


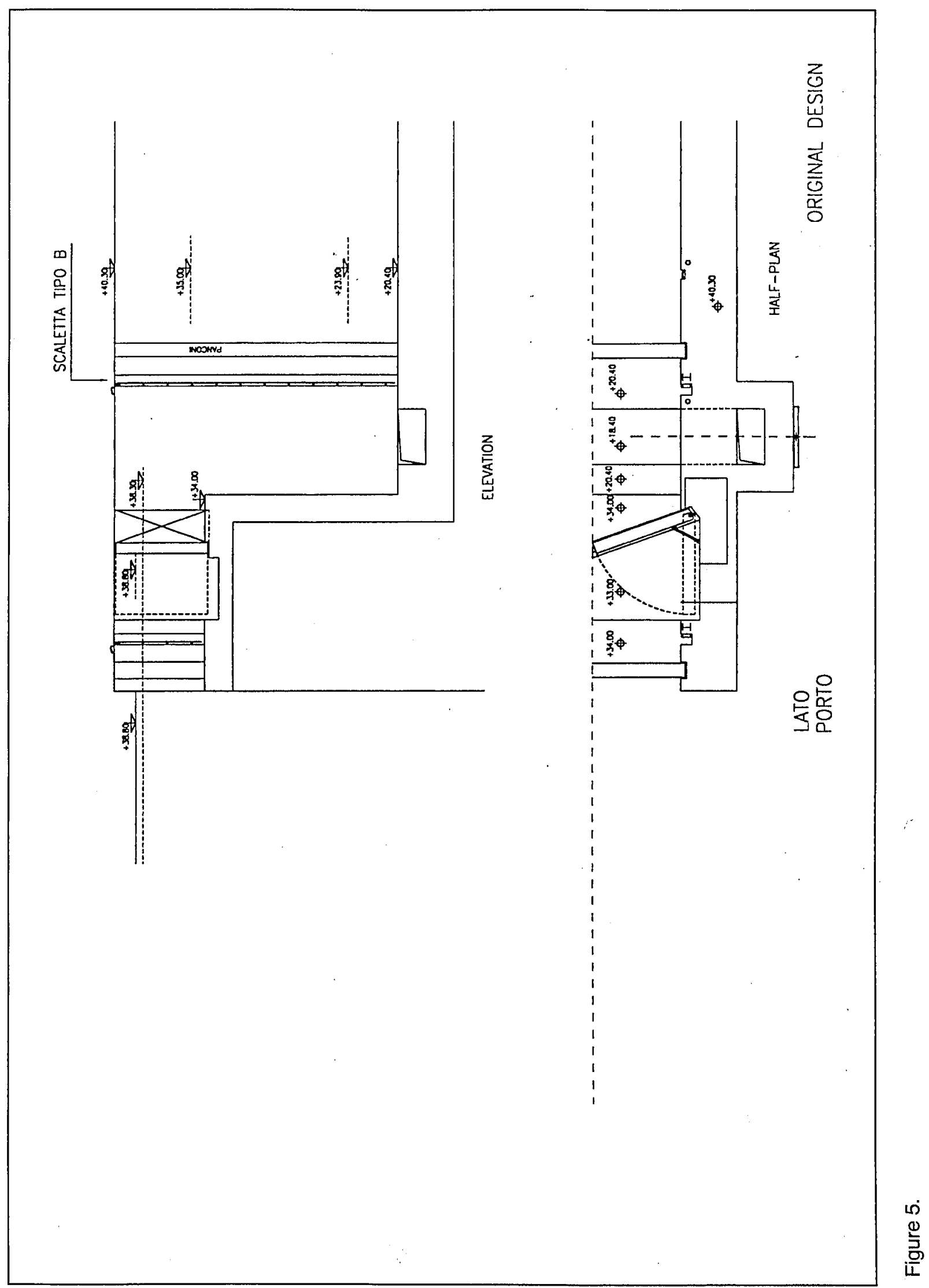




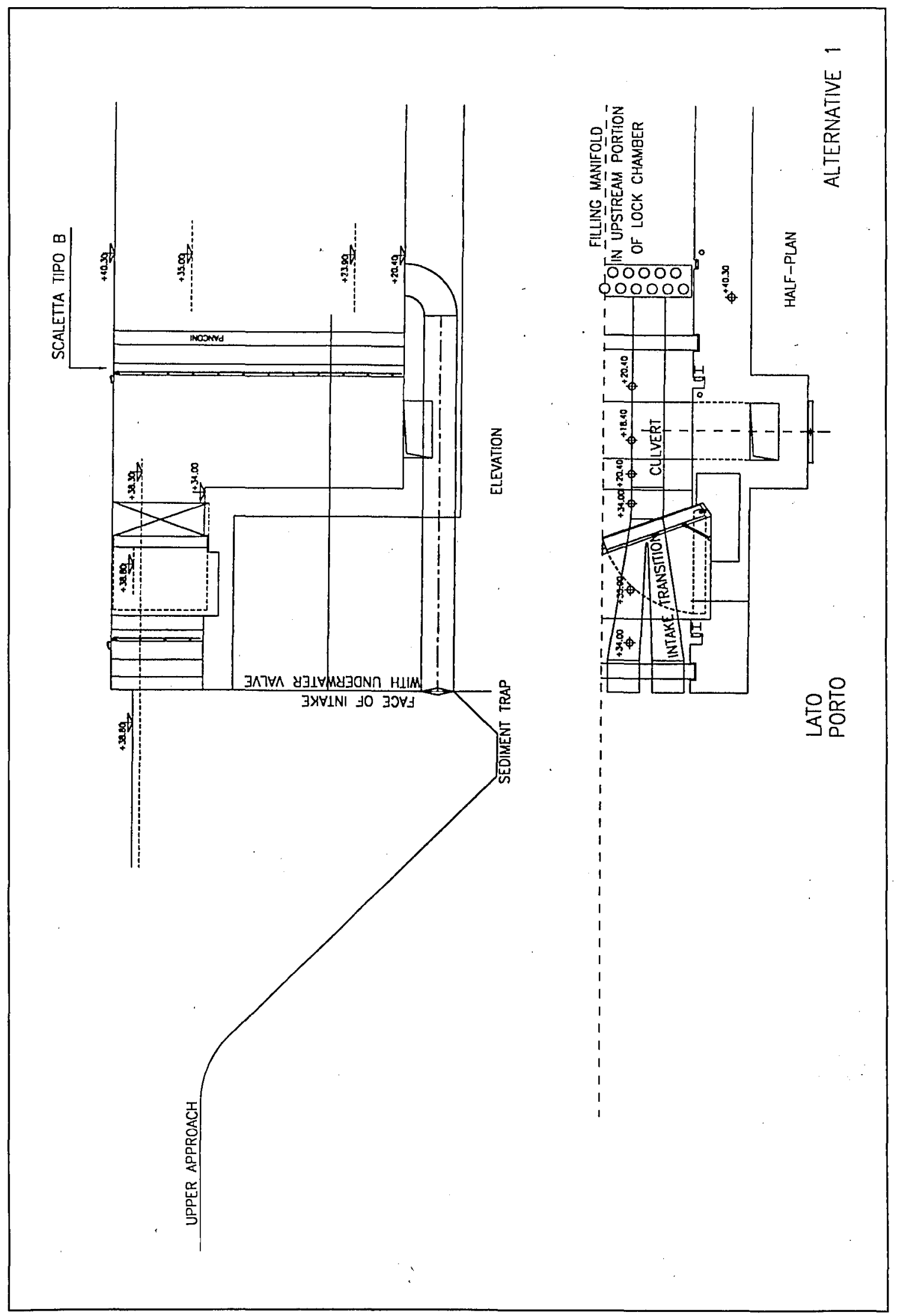

它 


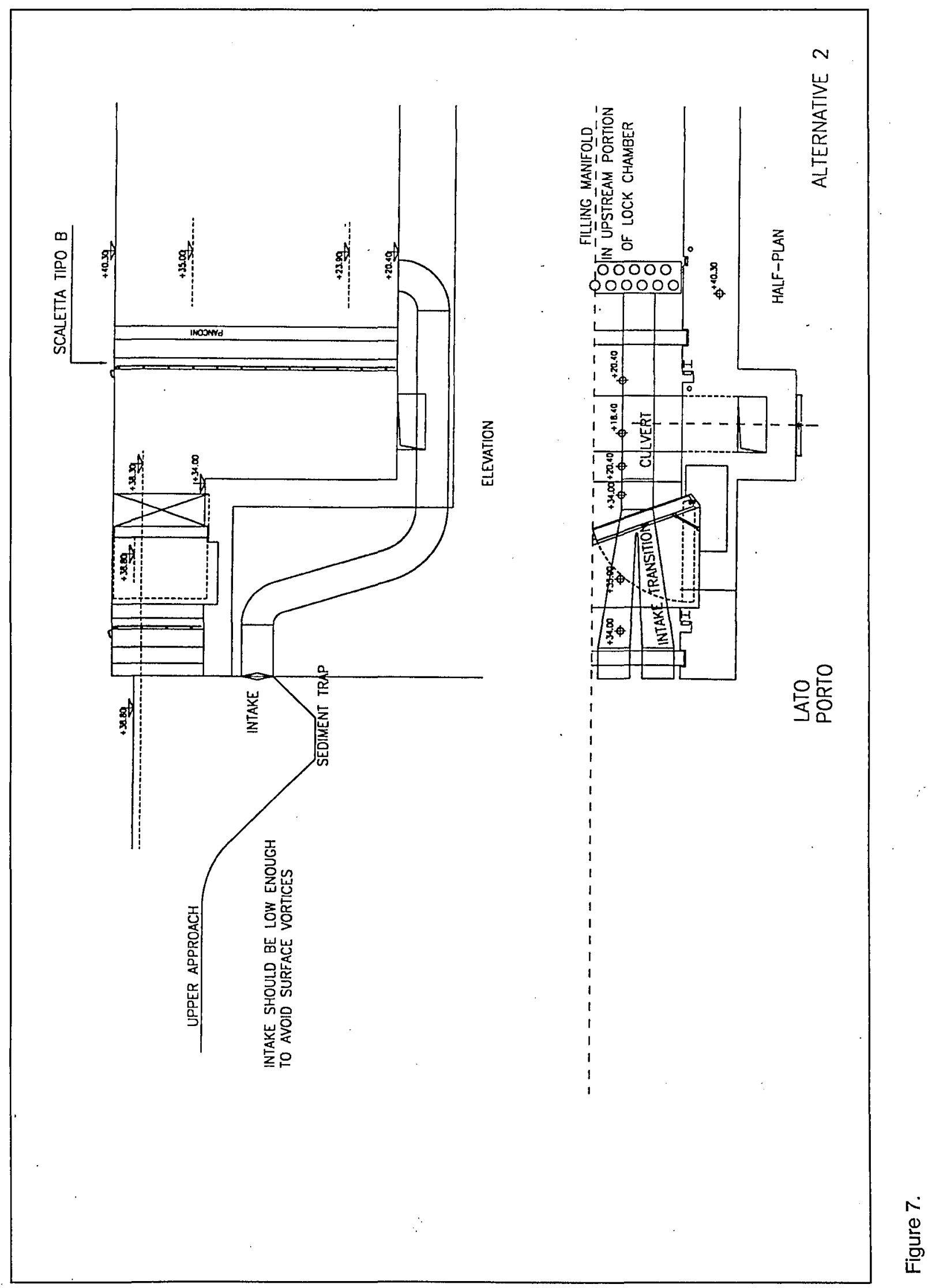




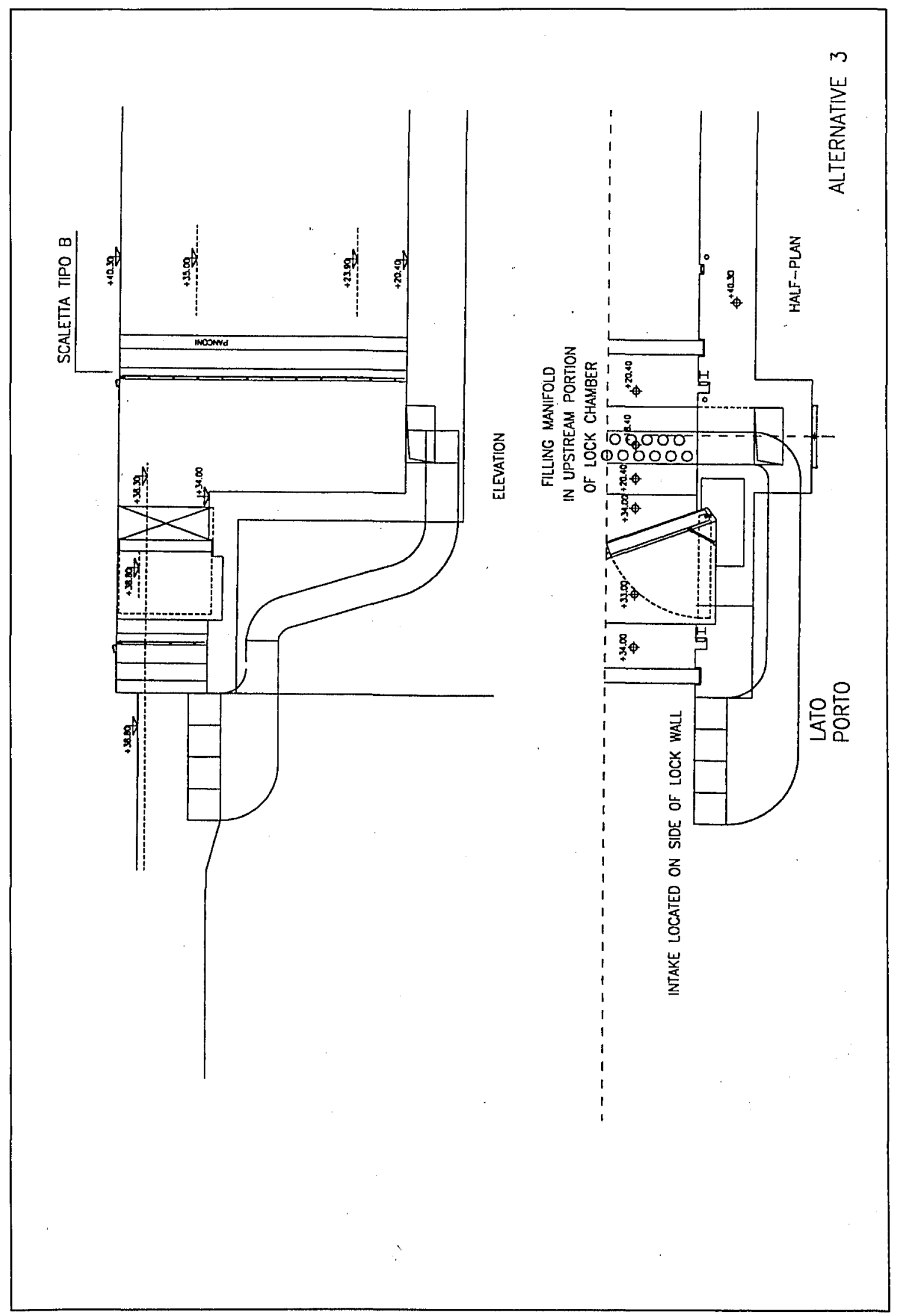

$\infty$
믹
믄 


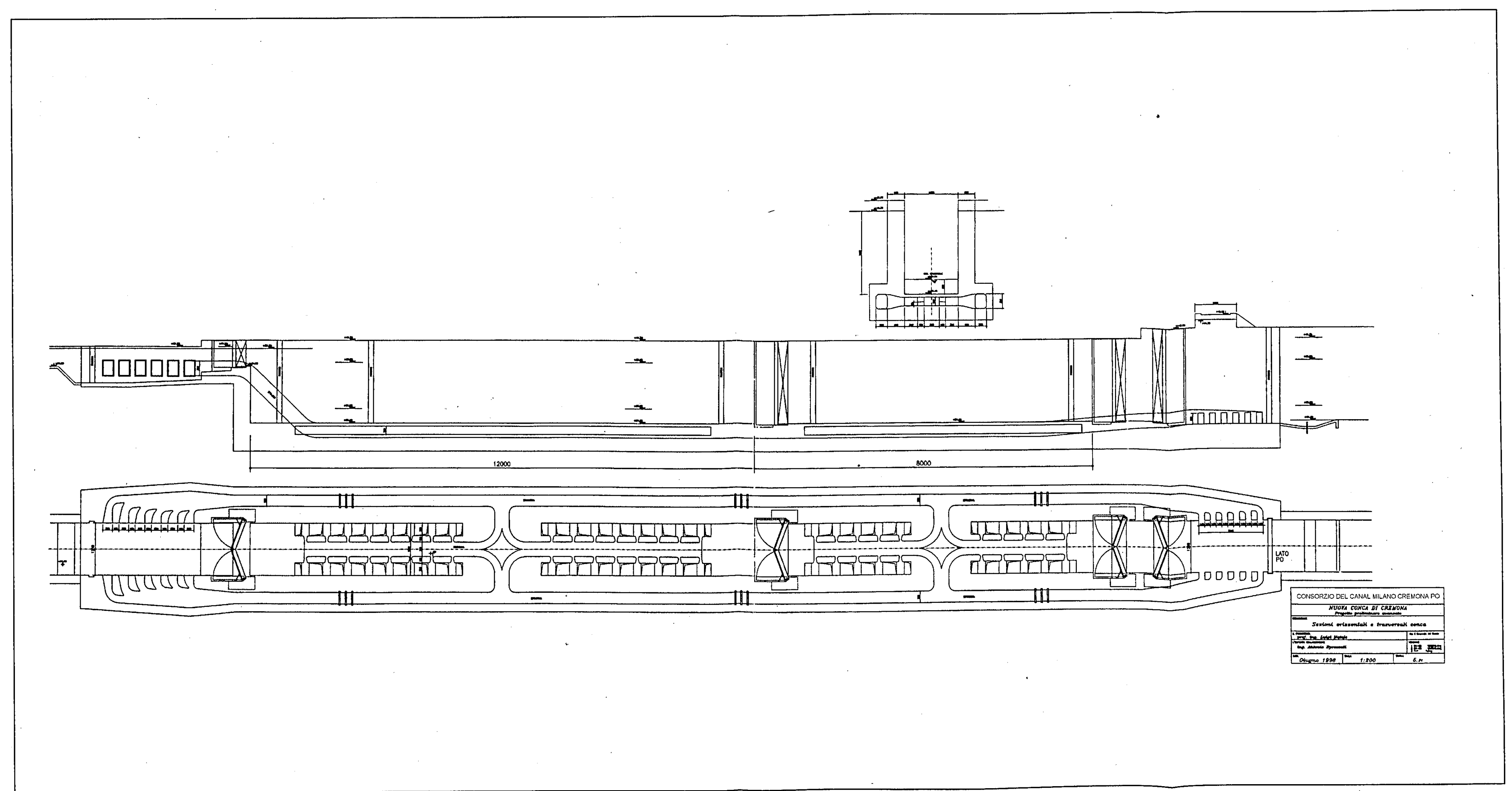

Figure 9. 


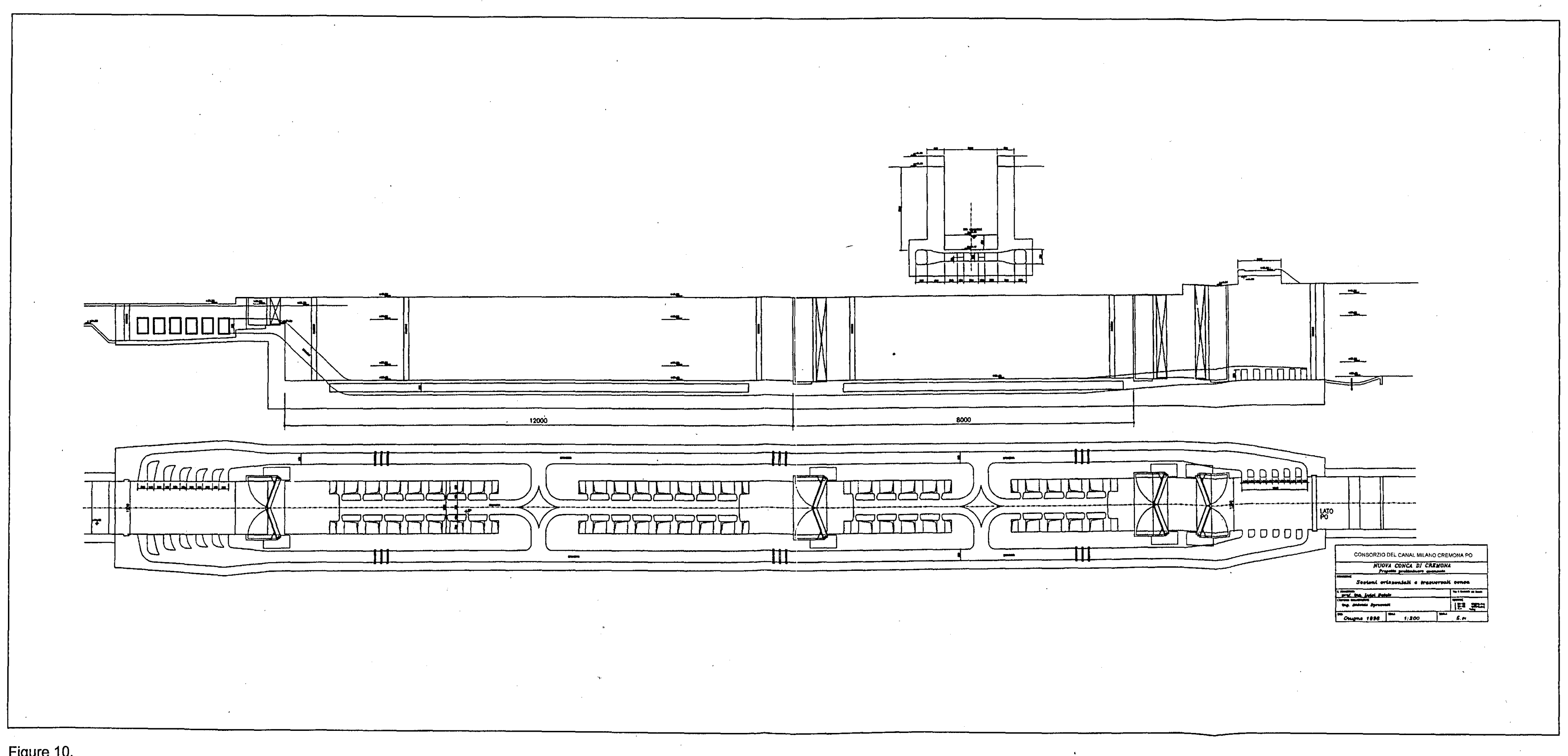




\section{Appendix A Cooperative Research and Development}


. 
WES AGREEMENT NO. WES-97-CHL-07

\section{COOPERATIVE RESEARCH AND DEVELOPMENT AGREEMENT \\ BETWEEN}

U.S. ARMY ENGINEER WATERWAYS EXPERIMENT STATION

AND

Dr. LUIGI NATALE

This Cooperative Research and Development Agreement (CRADA) is entered into by and between Dr. Luigi Natale, an independent engineering consultant, hereinafter referred to as "Partner" and the United States of America, as represented by the Director U.S. Army Engineer Waterways Experiment Station, Vicksburg, Mississippi, hereinafter referred to as "WES" pursuant to the authority contained in the Federal Technology Transfer Act (15 U.S.C. 3710a), as amended and Army Regulation 70-57.

Whereas, the Federal Technology Transfer Act of 1986 has provided each Federal agency with the authority to permit the Director of Government operated Federal laboratories to enter into CRDAs with Federal or non-Federal entities;

Whereas, the WES Coastal and Hydraulics Laboratory has the mission of planning and executing research and development investigations related to hydraulic structures and inland navigation, and

Whereas, the WES Coastal and Hydraulics Laboratory has expertise in riverine hydraulics, and

Whereas, the Partner is a consulting architect/engineer(A/E) firm conducting a study of navigation improvements on the Po River system, and

Whereas, the Partner has a need tfor access to certain unique facilities and capabilities at WES related to hydraulic structures and inland navigation, and

Whereas the Partner desires to collaborate with WES on this project, and

Whereas, the data and results from the study will be used by WES to update design criteria and manuals, Now, therefore, the parties hereto agree as follows:

\section{Article 1. Definitions}

As used in this Agreement, the following terms shall have the following meanings and such meanings should be equally applicable to both the singular and plural forms of the terms defined: 
1.1 Agreement means this cooperative research and development agreement.

1.2 Reviewing Official means the authorized representative of the Department of the Army who is a signatory of this Agreement.

1.3 Created, in related to any work under this Agreement, means that the work is fixed in any tangible medium of expression for the first time as defined in 17 U.S.C. 101.

1.4 Invention means any invention or discovery which is or may be patentable under Title 35 of the United States Code or under the laws of any other country.

1.5 Subject Invention means any invention conceived or first actually reduced to practice in the performance of work under this CRDA.

1.6 Data means all information first produced in the performance of this CRDA, both processed and unprocessed, generated from model testing and prototype implementation, and can either be numeric, alphanumeric, text, photographs, or other recorded forms.

1.7 Subject Data means all recorded information first produced in the performance of this CRDA.

1.8 Proprietary Information means information which embodies information which is confidential business or financial information provided that such information:

(1) Is not generally known or available from other sources without obligation concerning its confidentiality;

(2) Has not been made available by the owners without obligation concerning its confidentiality; and

(3) Is not already available without obligation concerning its confidentiality.

\section{Article 2. Cooperative Research and Development Program}

2.1 The purpose and object of this collaborative effort is to provide for the conduct of research and development activities utilizing the unique facilities and capabilities of WES to evaluate proposed navigation improvements to the Po River system, in northern Italy. The research and development consists of evaluation of lock siting, lock approaches, and analysis of riverine conditions. Lectures will also be conducted by WES researchers to elaborate on the collaborative efforts of the WES and Italian team. The respective obligations of the parties performing the cooperative research and development program are as follows:

\subsubsection{WES:}

(1) Subject to approval by Headquarters, U.S. Army Corps of Engineers, as appropriate, shall provide technical assistance by WES engineers, scientists, and technicians necessary to conduct evaluation of the proposed navigation improvements to the Po River system.

(2) Shall conduct lectures outlining the state of the knowledge on inland navigation structures.

\subsubsection{Partner:}

(1) Shall provide design information and data for the proposed navigation improvement at no cost, to the WES Coastal and Hydraulics Laboratory.

(2) Shall provide technical assistance in the evaluation of the navigation improvements .

(3) Shall provide funds to WES for all expenses related to the collaborative effort. 
(4) Shall neither transfer nor assign this CRDA nor grant any use, privilege, or license whatsoever in connection with this CRDA without permission in writing from or through the WES point of contact.

(5) Agrees that the U.S. Government and Corps of Engineers will not be liable for losses or injuries relating to the use of any erosion control products.

2.2 Periodic Reports. WES and Partner shall prepare periodic reports to each other during the terms of this Agreement on the progress of the collaborative work and the results being obtained and shall make available to each other, to the extent reasonably possible, other project information in sufficient detail to explain the progress of the work.

2.3 Review of Work. Periodic meetings may be held between WES and Partner personnel as required for the purpose of reviewing the progress of work. It is understood that the nature of this research is such that completion within the period of performance specified, or within the limits of financial support allocated, cannot be guaranteed. Accordingly, it is agreed that all research under this Agreement is to be performed on a best effort basis.

2.4 Technical Management. WES agrees to assign the work to be performed under this Agreement to the Coastal and Hydraulics Laboratory at WES. The work will be performed under the supervision of Dr. Phil Combs, who will have the responsibility for the scientific and technical conduct of this project for WES.

2.5 Scope Change. If at any time Dr. Combs determines that the research data dictates a substantial change in the direction of the work, WES shall promptly notify Partner and the parties shall jointly consider possible change.

\section{Article 3. Financial Obligations}

The cost of labor, supplies, materials, equipment, overhead, and other expenses, direct and indirect, computed in accordance with WES standard accounting procedures which are incurred by WES and are necessary to the performance of the work as agreed to by the parties are chargeable to Partner. Prior to the commencement of any work by WES, Partner will deposit with the WES Disbursing Officer funds in the amount of $\$ 3000.00$ to cover the estimated cost of work to be performed. Checks should be made payable to AF\&A Officer, USAEWES@ and forwarded to U.S. Army Engineer Waterways Experiment Station, CEWES-RM-FD, 3909 Halls Ferry Road, MS 39180-6199. A note should accompany the deposit citing this Agreement, the technical point of contact identified in paragraph 2.4, and a brief description of the purpose of the funds. Any funds on deposit over and above the total cost incurred will be refunded within a reasonable period of time after determination of final costs. In no event shall the costs incurred by the Government exceed the funds deposited by Partner. The Partner will pay for all travel expenses separately.

\section{Article 4. Data Rights and Publication}

4.1 Rights. The Subject Data which is compiled under this Agreement shall be prepared, analyzed, shared, and mutually interchanged by the parties.

4.2 Proprietary Information. WES agrees that any proprietary information furnished by Partner to WES under this Agreement, or in contemplation of this Agreement, shall be used, reproduced and disclosed by WES only for purpose of carrying out this Agreement, unless consent to such release is obtained from Partner. Partner shall place a proprietary notice on all information it delivers to WES under this Agreement which it asserts to be proprietary. 
4.3 Publications. WES and Partner agree to confer and consult prior to the publication of Subject Data to assure that no proprietary information is released and that patent rights are not jeopardized. Prior to submitting a manuscript for review which contains the results of the research under this Agreement, or prior to publication if no such review is made, each party shall be offered an ample opportunity to review such proposed publication and to file patent applications in a timely manner, if it is so entitled under this Agreement.

\section{Article 5. Patent and Other Intellectual Property Rights}

5.1 Limited Scope. The United States Government shall retain ownership in any technology to which it has title prior to this agreement. Likewise, Partner shall retain ownership in any technology to which he has title prior to this agreement.

5.2 Reporting. WES shall promptly report to Partner each Subject Invention relevant to this CRDA reported to WES by its employees. Partner shall promptly report to WES each Subject Invention reported to Partner by any of its employees.

5.3 Partner Employee Inventions. WES, on behalf of the U.S. Government, waives any ownership rights the U.S. Government may have in Subject Inventions made by Partner employees and agrees that Partner shall have the option to retain title in any such employee Subject Invention and to obtain patents therein. Partner shall notify WES within 90 days upon making this election and shall have the right to timely file patent applications on such Subject Invention at its own expense. Partner agrees to grant to the U.S. Government on its employees Subject Inventions a non-exclusive, irrevocable, paid-up license in the patents covering Subject Inventions to practice or have practiced, throughout the world by, or on behalf of the U.S. Government and such other rights as are specified herein. Such non-exclusive license shall be evidenced by a Confirmatory License Agreement prepared by Partner in a form satisfactory to WES. Such applications shall be filed prior to the running of any statutory bar period, priority period or any applicable filing deadline which will bar the granting of a patent or other intellectual property on the invention.

5.4 WES Employee Inventions. WES, on behalf of the U.S. Government, shall have the initial option to retain title to each Subject Invention made by its employees and to obtain patents therein. WES shall notify Partner within ninety (90) days upon making this selection and shall have the right to timely file patent applications on such Subject Invention at its own expense. Partner shall have the option to negotiate an exclusive license on any such inventions for a selected field of use for a reasonable fee.

5.5 Joint Inventions. In the case of an invention made jointly by employees of WES and Partner, the parties agree to negotiate the retention of patent rights by one or both of the parties. Such applications shall be filed prior to the running of any statutory bar period, priority period or any applicable filing deadline which will bar the granting of a patent or other intellectual property on the invention.

5.6 Royalties to the WES. In this or any foreign country in which Partner obtains title to a patent or other intellectual property rights grant on any Subject Invention made solely by WES employees, Partner shall pay to the WES a royalty based on a reasonable rate applied to a royalty base. Both the royalty rate and the royalty base shall be negotiated in good faith. The royalty rate and royalty base shall fairly reflect the relative contributions of the parties to the making of the Subject Invention and to the work under this agreement, the risks incurred by Partner, and the costs of subsequent research and development needed to bring the Subject Invention to the point of practical application.

\subsection{March in Rights. The WES has the right to require Partner, its assignees, or its exclusive} licensee to grant a non-exclusive or exclusive license in any field of use to a reasonable applicant(s) upon reasonable terms, on any Subject Invention upon a determination by the WES that (1) Partner has not taken, or is not expected to take, within a reasonable time, effective steps to bring the Subject Invention 
to the point of practical application in such field of use; (2) such action is necessary to alleviate health or safety needs which are not reasonably satisfied by Partner, its assignees or licensees; or (3) such action is necessary to meet requirements are not reasonably satisfied by Partner, its assignees, or licensees.

5.8 Filing of Patent Applications. The party having the right to retain title and file patent applications on a specific Subject Invention may elect not to file patent applications thereon in the United States or other countries provided it so advises the other party within $\mathbf{9 0}$ days from the date it reports the Subject Invention to the other party. Thereafter, the other party may elect to file patent applications on such Subject Invention and the party initially reporting such Subject Invention agrees to assign its right title and interest in such Subject Invention to the other party and cooperate with such party in the preparation and filing of patent applications thereon. The assignment of the entire right title and interest to the other party pursuant to this paragraph shall be subject to the retention by the party assigning title of a non-exclusive, irrevocable, paid-up license to practice, or have practiced, the Subject Invention throughout the world.

5.9 Patent Expenses. The expenses attendant to the filing of patent applications as specified above, shall be borne by the party filing the patent application. Each party shall provide the other party with copies of the patent applications it files on any Subject Invention along with the power to inspect and make copies of all documents retained in the official patent application files by the applicable patent office.

5.10 Prosecution of Patent Applications. Both parties agree to cooperate with the other in the preparation, filing and prosecution of patent or other intellectual property applications in this or any foreign country. Each party shall provide the other party with a copy of any patent or other intellectual property application filed in this or a foreign country within sixty (60) days after filing, along with the power to inspect the patent or other intellectual property application. In the case of Subject Inventions made jointly by WES and Partner employees, the WES will be granted a power of attorney on any patent or other intellectual property application filed on such inventions.

5.11 Transfer of Rights to Inventors. In this or any foreign country in which none of the parties to this CRDA elects to file a patent or other intellectual property rights application on a Subject Invention, any or all of the parties may transfer their patent or other intellectual property rights to the employee inventor(s) with the reservation of a non-exclusive, irrevocable, world-wide, paid up license to practice or have practiced the Subject Invention by or on behalf of the parties.

5.12 Maintenance Fees. Maintenance fees on any patent or other intellectual property grant in this and any foreign country shall be paid by the party responsible for filing the patent or other intellectual property application in this or the foreign country.

\section{Article 6. Representations and Warranties}

6.1 Representations and Warranties of WES. WES hereby represents and warrants to Partner as follows:

6.1.1 Mission. The performance of the activities specified by this Agreement are consistent with the mission of WES.

6.1.2 Authority. Except as indicated in Article 10, all prior reviews and approvals required by regulations or law have been obtained by WES prior to the execution of the Agreement. The WES official executing this Agreement has the requisite authority to do so.

6.2 Representations and Warranties of Partner. Partner hereby represents and warrants to WES as follows:

6.2.1 Organization. Partner is a consulting architect engineer (A/E)

6.2.2 Statement of Ownership. Partner operates in Italy. 
6.2.3 Power and Authority. Partner has the requisite power and authority to enter into this Agreement and to perform according to the terms thereof.

6.2.4 Due Authorization. The officers, directors and trustees of Partner have taken all actions required to be taken by law, articles of incorporation, its bylaws or otherwise, to authorize the execution and delivery of this Agreement.

6.2.5 No Violation. The execution and delivery of this Agreement does not contravene any material provision of, or constitute a material default under any material Agreement binding on Partner or any valid order of any court, or any regulatory agency or other body having authority to which Partner is subject.

\section{Article 7. Liability}

7.1 To the extent permitted by law, each PARTY assumes liability for the negligent actions of its employees or agents that are the cause of the injuries or damages that occur during the performance of this Agreement.

7.2 No Warranty. Except as specifically stated herein, WES makes no express or implied warranty as to any matter whatsoever, including the accuracy, or reliability of any information or data, whether tangible or intangible, made, developed or supplied under this Agreement, or the ownership, merchantability, or fitness for a particular purpose of the information, of the data made, developed or supplied.

7.3 Indemnification. Partner holds the U.S. Government harmless and indemnifies the Government against all liabilities, demands, damages, injuries, expenses and losses arising out of the use by Partner, or by any party acting on its behalf or under its authorization, or by any third party, of any information, of any data made, developed or supplied by Partner under this Agreement. This provision shall survive termination of this Agreement.

7.4 Force Majeure. Neither party shall be liable for any unforeseeable event beyond its reasonable control not caused by the fault or negligence of such party, which causes such party to be unable to perform its obligations under this Agreement (and which it has been unable to overcome by the exercise of due diligence), including, but not limited to, flood, drought, earthquake, storm, fire, pestilence, lightning and other natural catastrophes, epidemic, war, riot, civic disturbance or disobedience, strikes, labor dispute, or failure, threat or failure, or sabotage, or any order or injunction made by a court or public agency. In the event of the occurrence of such a Force Majeure event, the party unable to perform shall promptly notify the other party. It shall further use its best efforts to resume performance as quickly as possible and shall suspend performance only for such period of time as is necessary as a result of the Force Majeure event.

\section{Article 8. Term}

8.1 It is mutually recognized that the contemplated time periods for completion of this joint research effort are good faith guidelines subject to adjustment by mutual agreement, to fit circumstances as the effort proceeds. In no case will this CRDA extend beyond 2 years, unless it is revised in accordance with Article 12, paragraph 12.7 of this CRDA. It is further agreed that the provisions of Articles $3,4,5$, 7, and 12.9 and 12.12 shall survive the termination of this CRDA, whether by mutual consent or unilateral action.

8.2 Effective Date. This CRDA shall enter into force following final Agency review as specified in Article 10. 


\section{Article 9. Extension, Termination and Disputes}

9.1 Termination by Mutual Consent. Either Partner or WES may elect to terminate this CRDA, or portions thereof, at any time by mutual consent. In such event, the parties shall specify the disposition of all property, patents and other results of work accomplished or in progress, arising from or performed under this CRDA.

\subsection{Termination by Unilateral Action.}

9.2.1 Written Notice. Either party may unilaterally terminate this entire CRDA at any time by giving the other parties written notice, not less than 30 days prior to the desired termination date; provided, however, that no party shall have the right to terminate its obligation under Article 4.

9.2.2 Data Rights. If either party unilaterally terminates this CRDA pursuant to Clause, each party shall return any and all subject data developed by the other party which it may have in its possession and will retain no rights to publish said subject data developed by the other party after the effective date of the unilateral termination.

9.3 Disputes. Any dispute arising under this CRDA which cannot be readily resolved shall be submitted jointly to the signatories of this CRDA with each party agreeing to seek in good faith to resolve the issue through negotiation or other forms of non-binding alternative disputes resolution mutually acceptable to the parties. A joint decision of the signatories or their designees shall be the disposition of such dispute.

9.4 Continuation of Work. Pending the resolution of any dispute or claim pursuant to this Article, the parties agree that performance of all obligations shall be pursued diligently.

\section{Article 10. Agency Review}

10.1 Authority. All prior reviews and approvals required by regulations or law have been obtained by WES prior to the execution of this CRDA. Notwithstanding the delegation of authority to execute this CRDA to the individual designated, the Secretary of the Army has reserved to the Assistant Secretary of the Army (Research, Development and Acquisition) the opportunity provided by 15 United States Code $3710 \mathrm{a}(\mathrm{c})(5)(\mathrm{A})$, to disapprove or require the modification of this CRDA within 30 days of the date it is presented to him by WES.

10.2 Ratification. In the event that the Assistant Secretary of the Army (Research Development and Acquisition) exercises the authority reserved by paragraph 10.1, Partner shall have 30 days from notification of the required modification to ratify the modifications or terminate the CRDA.

\section{Article 11 Equal Opportunity}

11.1 Equal Opportunity. During the performance of this CRDA, Partner shall comply with Executive Order 11246, as amended, and the rules, regulations, and orders of the Secretary of Labor concerning equal employment opportunity.

11.2 Disputes. Notwithstanding any other clause in this CRDA, disputes relative to this Article 11 will be governed by the procedures in 41 CFR 60-1.1, et seq.

\section{Article 12. Miscellaneous}

12.1 No Benefits. No member of, or delegate to the United States Congress, or resident commissioner, shall be admitted to any share or part of this Agreement, nor to any benefit that may arise therefrom; but this provision shall not be construed to extend to this Agreement if made with a corporation for its general benefit. 
12.2 Governing Law. The construction, validity, performance and effect of this Agreement for all purposes shall be governed by the laws applicable to the Government of the United States.

12.3 Entire Agreement. This Agreement constitutes the entire Agreement between the parties concerning the subject matter hereof and supersedes any prior understanding or written or oral Agreement relative to said matter.

12.4 Headings. Titles and headings of the Sections and Subsections of this Agreement are for the convenience of references only and do not form a part of this Agreement and shall in no way affect the interpretation thereof.

12.5 Waivers. None of the provisions of this Agreement shall be considered waived by any party hereto unless such waiver is given in writing to all other parties. The failure of any party to insist upon strict performance of any of the terms and conditions hereof, or failure or delay to exercise any rights provided herein or by law, shall not be deemed a waiver of any rights of any party hereto.

12.6 Severability. The illegality or invalidity of any provisions of this Agreement shall not impair, affect or invalidate the other provisions of this Agreement.

12.7 Amendments. If either party desires a modification in this Agreement, the parties shall, upon reasonable notice of the proposed modification by the party desiring the change, confer in good faith to determine the desirability of such modification. Such modification shall not be effective until a written amendment is signed by all the parties hereto by their representatives duly authorized to execute such amendment.

12.8 Assignment. Neither this Agreement nor any rights or obligations of any party hereunder shall be assigned or otherwise transferred by either party without the prior written consent of the other party.

12.9 Export Controls Laws. Partner is hereby placed on legal notice that by Federal Law, 15 CFR 779, an export license from the Department of Commerce may be required before exporting data or commodities to a foreign country or a foreign person within the United States. The controlling law is the Export Administration Act of 1979 and 1981, 50 U.S.C. 2401-2420 and the implementing regulations at 15 C.F.R. 768.1-799.

12.10 Drug-Free Workplace. During the performance of this CRDA, Partner shall be required to comply with the intent of the Drug-Free Workplace Act of 1988, 41 U.S.C. 701, et seq, which requires the establishment of a drug-free workplace.

12.11 Title to Property. The purchase or use of any property to carry out this CRDA does not affect the ownership rights that would otherwise apply. However, property directly provided under this CRDA by either party, regardless of who uses the property in the performance of the work, shall remain the property of the providing party unless other disposition is mutually agreed upon in writing by the parties. The party holding the title to the equipment is responsible for the maintenance of the equipment and the costs of transportation to and from the site where it will be used.

12.12 Use of Name or Endorsements. The Government and the federal laboratory will not directly or indirectly endorse any product or service provided by the Partner as a result of the CRDA.

12.13 Independent Contractors. The parties to this Agreement are independent contractors and are not agents of each other, joint venturers, partners or joint parties to a formal business organization of any kind. Neither party is authorized or empowered to act on behalf of the other with regard to any contract, warranty or representation as to any matter and neither party will be bound by the acts or conduct of the other. Each party will maintain sole and exclusive control over its own personnel and operations.

12.14 Covenant Against Contingent Fees. Partner warrants that no person or selling agency has been employed or retained to solicit or secure this CRDA upon agreement or understanding for a commission, 
percentage, brokerage, or contingent fee, excepting bona fide employees or bona fide established commercial or selling agencies maintained by Partner for the purpose of securing business. For breach or violation of this warranty, the WES shall have the right to annul this CRDA without liability, or, in its discretion, to add to the CRDA price or consideration, or otherwise recover, the full amount of such commission, percentage, brokerage, or contingent fee.

\section{Article 13. Notices}

All notices pertaining to or required by this CRDA shail be in writing and shall be signed by an authorized representative and shall be delivered by hand or sent by certified mail, return receipt requested, with postage prepaid, addressed as follows:

For WES: $\quad$ Director

U.S. Army Engineer Waterways Experiment Station

3909 Halls Ferry Road

Vicksburg, MS 39180-6199

For Partner: $\quad$ Dr. Luigi Natale

c/o HYDRAW srl

via S. AGATA, 10

27100 PAVIA

ITALY

Phone 3938229210

Either party may change such address by notice given to the other parties in the manner set forth above.

In WITNESS WHEREOF, the parties have caused this Agreement to be executed in duplicate by their duly authorized representatives as follows:

\section{For Partner:}

LUIGI NATALE, PhD,

Date

For U.S. Government

ROBERT W. WHALIN, PhD, PE

Date Director 


\section{Appendix B Trip Report}




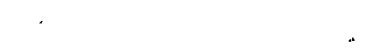


SUBJECT: Report of Trip to Italy Regarding the Cremona Replacement Lock Po River, 25-29 Oct 1997

1. OBJECTIVES OF TRIP: As part of CRDA with Dr. Luigi Natale, provide collaborative research and development insight for Cremona Replacement Lock, Po River.

2. PLACES and DATES VISITED: a)Mantova, Italy , 26-28 Oct 1997, b) Parma, Cremona and Pavia, Italy, 28 Oct 1997 and c) Pavia and Milan, Italy, 29 Oct 1997.

3. SUBJECTS DISCUSSED: The following is a synopsis of the visit to Northern Italy:

As a result of a CRDA with Dr. Luigi Natale, the U. S. Army Corps of Engineers Waterways Experiment Station(WES) was to conduct collaborative research on the proposed Cremona Lock, Po River. As a part of the CRDA, Dr. Combs was to visit the existing lock, the proposed lock site and pprovide insight utilizing the latest research technology in innovative lock design to Dr. Natale and the project sponsor.

\section{Oct 1997}

After arrival in Milan, Italy at 0800 , Dr. Luigi Natale took the undersigned to Mantova, Italy, about a 2 hour drive east of Milan. After settling into the hotel, Dr. Natale conducted a tour of the area to three locks of different vintage. Th first lock, which was inoperable, located near Governolo, Italy, was constructed in 1887. This lock was no longer directly connected to a canal, but it was obvious that it had wooden miter gates. The size was about 24 meters long and about 6 meters wide. Nearby was a functional lock that was built about 60 years ago. This lock is 45 meters long and 8 meters wide. The lock has vertical slide gates with the filling and emptying occurring under the slide gates.

We then viewed a new lock completed last year at Governolo, Italy, southwest of Mantova. This lock is also 200 meters long and 12.3 meters wide. This lock also has vertical slide gates and end filling and emptying under the gates. This lock has a secondary set of gates located at the 80 meter point. These gates may be operated as the upper gates when the tow is small. Dr. Natale told me that inclusion of a supplemental set of lock gates is common in Italy. The smaller chamber allows faster transit through the lock.

Dr. Natale told me that the existing as well as the replacement lock for Cremona are similar to this lock, 200 meters long and 12 meters wide. The Cremona locks also have an end filling and emptying system. Dr. Natale and I went to the office of Engineer Antonio Sproccati to discuss the replacement lock. Sprocatti is conducting the structural design of the lock. We had a considerable discussion about the merits of a distributed filling and emptying system compared to the end filling system. Dr. Natale said that the sponsor had decided that they wanted an end filling system to minimize cost. However, they need the latest research technology from WES to assure a safe operating system. I told him that we have a standard criteria that hawser stresses should not exceed 5 tons for a shallow draft lock. He said they had conducted numerical evaluations and had concluded that the end filling system would not exceed the 5 ton limit. He said they could slow the filling and emptying down, if necessary, in 
order to meet the 5 ton limit. Dr. Natale said that since the lock filling and emptying was only a portion of the total transit time, a small increase in filling and emptying time would be acceptable. Dr. Natale showed me plan views of the existing lock and the new lock. He furnished me a copy of these plans.

\section{Oct 27}

Engineer Sproccati picked me up at hotel and we had extensive discussions at his office about new lock design criteria. He and Dr. Natale previously designed a new lock connecting Inferior Lake to the canal( the canal will eventually will connect Mantova to the Adriatic Sea). This lock has not been constructed. We also discussed several different conceptual plans for the end filling and emptying system.

\section{$28 \mathrm{Oct}$}

Engineer Sproccati and I went to Parma, Italy for a meeting at the Ministry of Public Works at 9:30. We met Dr. Natale at the Ministry of Public. Works building. There were about 30 engineers in attendance, including the President and Technical Director of the Cremona Port, President of Magistrata of Po River (responsible for Po River River training structures), and the President of the ARNI (agency responsible for Po River navigation). A delegation from ARNI visited WES in May 1996. I met several engineers that I had met in May 1996 at WES. The ARNI engineers expressed an interest in developing a relationship with WES to improve the navigability of the Po River and also to assist in developing electronic charting on the Po River.

The purpose of the meeting was to have technical discussions on the Po River and the Red River. I had been asked to provide a technical briefing on the Red River, the design aspects of the locks, the techniques used for river stabilization and sedimentation aspects and a briefing on our latest research in shallow draft locks. There were several speakers that discussed the technical aspects of the Po River, in Italian. Dr. Natale did the translation for me. I made two presentations to the group; 1) present research being conducted on navigation locks, including the new innovative concepts and 2) a technical briefing on the Red River. It became clear the Po and Red Rivers are very similar in size, hydrology and sediment transport. The group was very interested in learning more about the Corps experiences on the Red River and more indepth technology transfer.

After the meeting, Dr. Natale, Engineer Sprocatti and I proceeded to Cremona to view the existing lock and the site of the proposed lock. The existing lock consists of 2 inline locks with the upstream one being $12 \mathrm{~m}$ wide and $226 \mathrm{~m}$ long. The adjacent downstream lock was constructed, more recently, of a floating steel and concrete lock to accommodate the degradation of the Po River. There is a supplementary set of gates at the $87 \mathrm{~m}$ location for small tows. The gates are vertical lift gates and the filling and emptying is performed under the gates. The head on the lock was about $5.5 \mathrm{~m}$, since the river was at low water. The need for the replacement lock is due to the degradation occurring on the Po River. The existing locks are not satisfactory for the total expected degradation. The lockmaster performed a filling and emptying operation to demonstrate the system. I had emphasized to Dr. Natale and Engineer Sprocatti the need to have a distributed system to assure that the hawser stresses do not exceed 5 tons. Dr. Natale assured me that the end filling system would not exceed the 5 ton load. The filling cycle demonstrated in photo 1 was not anything like a filling cycle in the U.S. The differential head was about 5.5 meters, about the existing maximum differential head. The filling cycle was accomplished as fast as possible with excessive turbulence in the chamber. No tow was in the chamber, but the lockmaster said he would only slow the filling cycle slightly for a tow in the chamber. He said it is common practice for the tows to be in gear in order to resist the filling forces. This lock has a barrier to resist the tow from backing into the miter gate. Overall the condition of the lock was in poor condition. The concrete was cracking and broken, the lock leaked through the walls and there were no safety rails along the lock. 
We visited the site of the proposed Cremona lock, which is located just west of the existing lock. The Po River is expected to degrade an additional as much as 6.5 meters, which will render the existing lock unserviceable. The new lock and channel will be designed to accommodate the anticipated degradation.

Dr. Natale and I then proceeded to Pavia for the night.

29 Oct

Dr. Combs had closing discussions with Dr. Natale while enroute to the Milan airport. I departed Milan at 1215(local time) for eventual arrival in Jackson; Mississippi at 2110 (local time).

PHIL G. COMBS, PhD, PE

Chief, Rivers and Structures Division

Coastal \& Hydraulics Laboratory, WES 


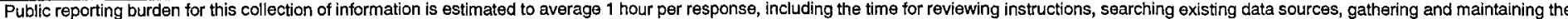

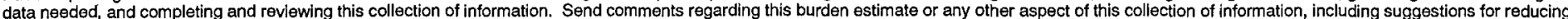

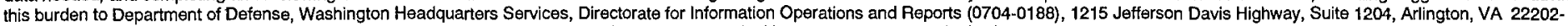

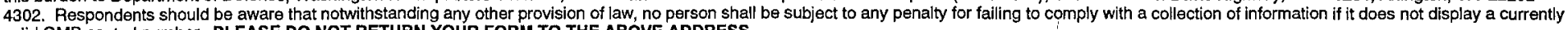
valid OMB control number. PLEASE DO NOT RETURN YOUR FORM TO THE ABOVE ADDRESS

1. REPORT DATE (DD-MM-YYYY) 2. REPORT TYPE

March 2000

4. TITLE AND SUBTITLE

Site Visit and Evaluation of New Cremona Lock Filling and Emptying System Final Report

3. DATES COVERED (From - To)

5a. CONTRACT NUMBER

5b. GRANT NUMBER

5c. PROGRAM ELEMENT NUMBER

6. AUTHOR(S)

Phil G. Combs

5d. PROJECT NUMBER

5e. TASK NUMBER

5f. WORK UNIT NUMBER

8. PERFORMING ORGANIZATION REPORT NUMBER

U.S. Army Engineer Research and Development Center

Coastal and Hydraulics Laboratory

3909 Halls Ferry Road

Vicksburg, MS 39180-6199

9. SPONSORING / MONITORING AGENCY NAME(S) AND ADDRESS(ES)

Dr. Luigi Natale

HYDRAW srl

S. Agata, 10

27100 Pavia, Italy

12. DISTRIBUTION / AVAILABILITY STATEMENT

Approved for public release; distribution is unlimited.
ERDC/CHL SR-00-1

10. SPONSOR/MONITOR'S ACRONYM(S)

11. SPONSOR/MONITOR'S REPORT NUMBER(S)

\section{SUPPLEMENTARY NOTES}

\section{ABSTRACT}

The work described herein was performed in the Coastal and Hydraulics Laboratory of the U.S. Army Engineer Waterways Experiment Station(WES) as part of a Cooperative Research and Development Agreement(CRDA) with Dr. Luigi Natale, Pavia, Italy. The CRDA entailed collaborative research involving innovative techniques for design of navigation locks to be incorporated into a replacement lock at Cremona, Italy. This report presents findings and recommendations of the collaborative efforts.

\section{SUBJECT TERMS}

Distributed manifold system

Hawser stresses

Hydraulic scale model

nnovative Techniques for filling and emptying

filling and emptying system

\section{SECURITY CLASSIFICATION OF:}

1. REPORT

UNCLASSIFIED b. ABSTRACT UNCLASSIFIED
Miter gates

Navigation lock

Po River

Vertical lift gates

Wrap around culverts

17. LIMITATION
OF ABSTRACT
OF ABSTRACT
18. NUMBER
OF PAGES

41 19a. NAME OF RESPONSIBLE PERSON

19b. TELEPHONE NUMBER (include area code) 
